\title{
Elevated EBV DNA
}

National Cancer Institute

\section{Source}

National Cancer Institute. Elevated EBV DNA. NCI Thesaurus. Code C158663.

A finding indicating elevated concentrations of Epstein-Barr virus DNA in a sample. 